\title{
Inhibition of bull and rabbit sperm enzymes by $\alpha$-chlorohydrin*
}

\author{
C. H. Yang and P. N. Srivastava \\ Reproduction Research Laboratories, Department of Biochemistry, University of Georgia, \\ Athens, Georgia 30602, U.S.A.
}

\begin{abstract}
Summary. High concentrations of $\alpha$-chlorohydrin were found to inhibit hyaluronidase, $\beta$-glucuronidase, and aryl sulphatases in bull and rabbit spermatozoa, but not acrosin and neuraminidase. Preincubation of the enzyme and $\alpha$-chlorohydrin was essential to achieve the maximum inhibition which was irreversible.
\end{abstract}

\section{In troduction}

The administration of $\alpha$-chlorohydrin (3-chloro-1,2-propanediol) is known to produce infertility in the males of many species but its mode of action remains uncertain. It is generally believed that the compound induces reversible sterility without interfering with spermatogenesis and mating behaviour. Ericsson \& Baker (1970), Samojlik \& Chang (1970) and Turner (1971) considered that effect of the drug was on the epididymis. Gunn, Gould \& Anderson (1969) and Coppola (1969) suggested that the compound might act as a metabolic antagonist to glycerol in phospholipid synthesis. Vickery, Erickson \& Bennett (1974) found that the motility and transport of spermatozoa recovered after mating was inhibited as a result of changes in semen composition. Johnson \& Pursel (1973) proposed that the mechanism of action of $\alpha$-chlorohydrin might involve blockage of an enzyme site or sites on the sperm cell.

The epididymal tissue and seminal plasma are known to contain high concentrations of glycosidases, particularly $\beta-N$-acetyl-glucosaminidase (Conchie, Findlay \& Levvy, 1959), $\beta$-glucuronidase (C. H. Yang, unpublished) and hyaluronidase (Yang \& Srivastava, 1972). In this report, the effect of $\alpha$-chlorohydrin on partly purified enzymes present in bull semen and in rabbit sperm acrosomal extracts were tested.

\section{Materials and Methods}

The $\alpha$-chlorohydrin $\left(99 \%\right.$ pure, mol. wt $110 \cdot 54$, b.p. $215^{\circ} \mathrm{C}$ ) was obtained from Aldrich Chemical Company, Inc. Hyaluronic acid (Grade III-P, Lot 92C-2640), $p$-nitrophenyl- $N$-acetyl- $\beta$-D-glucosaminide (Grade III), phenolphthalein glucuronic acid (sodium salt), and $p$-nitrocatechol sulphate (dipotassium salt) were purchased from Sigma Chemical Co. Benzoyl arginine ethyl ester (BAEE) was obtained from Schwartz/Mann Co. Azocoll was obtained from Calbiochem. All other chemicals were of the highest purity available. Three glycosidases, hyaluronidase, $\beta$ - $N$-acetyl-glucosaminidase and $\beta$-glucuronidase, were prepared by fractionation of a $105,000 \mathrm{~g}$ supernatant of bull seminal

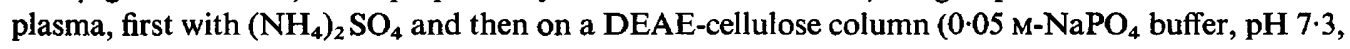
stepwise gradient) (Yang \& Srivastava, 1975). Rabbit acrosomal extract was prepared by the detergent treatment (Srivastava, Zaneveld \& Williams, 1970).

Enzyme assays. The methods used were those described by Yang \& Srivastava (1974b) for aryl sulphatase, Yang \& Srivastava (1974a) for hyaluronidase, Yang \& Srivastava (1975) for $\beta$-glucuronidase and Srivastava et al. (1970) for sperm neuraminidase. $\beta$ - $N$-acetyl-glucosaminidase was estimated by the method of Tarentino \& Maley (1972). Acrosin was measured spectrophotometrically using benzoyl-L-arginine ethyl ester, and other proteinases were determined by hydrolysis of azocoll, a general substrate for proteinases, as described by Srivastava, Munnell, Yang \& Foley (1974).

\footnotetext{
* Correspondence and reprint requests to Dr P. N. Srivastava.
} 
Enzyme inhibition studies were carried out by preincubation of the inhibitor and the enzyme before adding substrate and also by adding the inhibitor to the assay system containing the enzyme and the substrate. The preincubation was carried out in a total volume of $1 \mathrm{ml}$ containing $0.5 \mathrm{ml}$ enzymes(hyaluronidase, 6 munits $/ \mathrm{ml}$; arylsulphatase A or B, 8 munits $/ \mathrm{ml} ; \boldsymbol{\beta}$-glucuronidase, 16 munits/ $\mathrm{ml} ; \beta$ - $N$-acetylglucosaminidase, 0.9 units $/ \mathrm{ml}$; acrosin, $250 \mathrm{munits} / \mathrm{ml}$; azocoll proteinase, 820 units/ $\mathrm{ml}$; neuraminidase, $0.32 \mathrm{units} / \mathrm{ml}$ ) and different concentrations of the inhibitor at $37^{\circ} \mathrm{C}$ for $15 \mathrm{~min}$. The enzyme alone made up to $1 \mathrm{ml}$ with the buffer was similarly preincubated. The final concentration of inhibitor was calculated on the basis of total reaction volume for each enzyme assay.

Tests for reversibility by the method of Ackerman and Potter. The enzyme concentration was varied in the absence of $\alpha$-chlorohydrin and with two or three concentrations of $\alpha$-chlorohydrin (Ackerman \& Potter, 1949). This method is suitable for an enzyme-inhibitor system with a very high affinity of enzyme for inhibitor and a small dissociation constant. The reversibility of hyaluronidase (31 munits $/ \mathrm{ml})$, aryl sulphatase $(82$ munits $/ \mathrm{ml})$ and $\beta$-glucuronidase $(8 \mathrm{munits} / \mathrm{ml})$ was tested using $1 \cdot 2$ mg hyaluronic acid in $0.5 \mathrm{ml}$ reaction mixture, $3 \mathrm{~mm}$-nitrocatechol sulphate in $0.5 \mathrm{ml}$ reaction mixture, and $0.01 \mathrm{M}$-phenolphthalein glucuronate in $1 \mathrm{ml}$ reaction mixture as substrate respectively. The reversibility of the enzyme-inhibitor complex was also tested by checking the activity after dialysis of the enzyme-inhibitor system. The enzyme and inhibitor were incubated for $15 \mathrm{~min}$ at $37^{\circ} \mathrm{C}$ and dialysed against distilled water for $4 \mathrm{hr}$. The activities of the enzyme-inhibitor system after incubation and dialysis were compared with those of controls.

Lineweaver-Burk plot for $K_{i}$. For estimation of $K_{i}$ values for inhibition of hyaluronidase and $\beta$-glucuronidase by $\alpha$-chlorohydrin, the substrate concentration was varied in the absence and presence of a single concentration of the inhibitor. Values for $K_{i}$ were calculated in the usual manner for non-competitive inhibition (Webb, 1963). Since the two isoenzyme activities of arylsulphatase A and $B$ are estimated by different concentrations of the same substrate, the method was not applicable to aryl sulphatase.

\section{Results}

Glycerol (25\%) was used as a control and enzyme activity was not affected. $\alpha$-Chlorohydrin did not show any effect on chromogen formation in the hyaluronidase assay when the compound was added to the assay mixture after completion of the reaction with the enzyme.

As shown in Text-fig. 1(a), hyaluronidase ( 3 munits $/ \mathrm{ml}$ ) was completely inactivated by a concentration of $120 \mathrm{~mm}$ of the inhibitor when they were preincubated. At a lower concentration of the inhibitor, i.e. $59 \mathrm{~mm}$, hyaluronidase was partly inhibited. Preincubation of aryl sulphatase A ( 8 munits $/ \mathrm{ml}$ ) or B $(8 \mathrm{munits} / \mathrm{ml})$ with the inhibitor resulted in complete inhibition by $80 \mathrm{~mm} \alpha$-chlorohydrin (Text-fig. 1b). $\beta$-Glucuronidase $(0.2$ munits $/ \mathrm{ml})$ activity was completely inhibited by $50 \mathrm{~mm}$ - $\alpha$-chlorohydrin, but only partly inhibited if there was no preincubation (Text-fig. 1c).

$\beta-N$-acetylglucosaminidase was partly inhibited by the highest concentration of $\alpha$-chlorohydrin $(1.2 \mathrm{M})$ tested. Acrosin, azocoll hydrolysis and neuraminidase from rabbit sperm acrosomal extracts were not inhibited when incubated with $2 \cdot 4,1 \cdot 0$ or $0.6 \mathrm{M}-\alpha$-chlorohydrin.
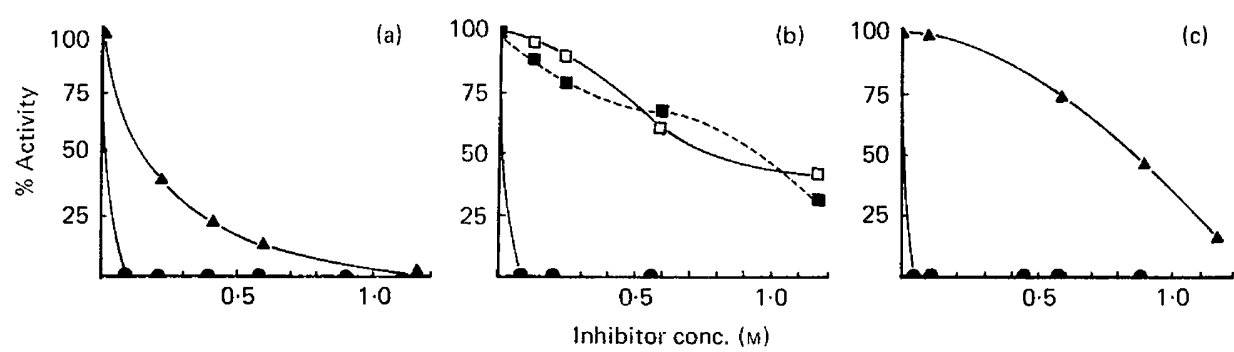

Text-fig. 1. Activity curves of inhibition of (a) hyaluronidase from bull seminal plasma, (b) aryl sulphatases A ( $\square$ ) and B (E) from rabbit acrosomal extracts, and (c) $\beta$-glucuronidase from bull ejaculated seminal plasma by $\alpha$-chlorohydrin. $\bullet$, Samples preincubated for $15 \mathrm{~min}$ at $37^{\circ} \mathrm{C}$; $\Lambda$, incubation with inhibitor. 
Ackerman-Potter plots of reaction velocity against enzyme concentration without $\alpha$-chlorohydrin (control) and at two inhibitor concentrations are shown in Text-fig. 2. Since the slopes of the inhibitor lines are displaced to the right by amounts proportional to the amount of inhibitor (Ackerman \& Potter, 1949), it appeared that hyaluronidase, aryl sulphatase and $\beta$-glucuronidase were irreversibly inhibited by $\alpha$-chlorohydrin.
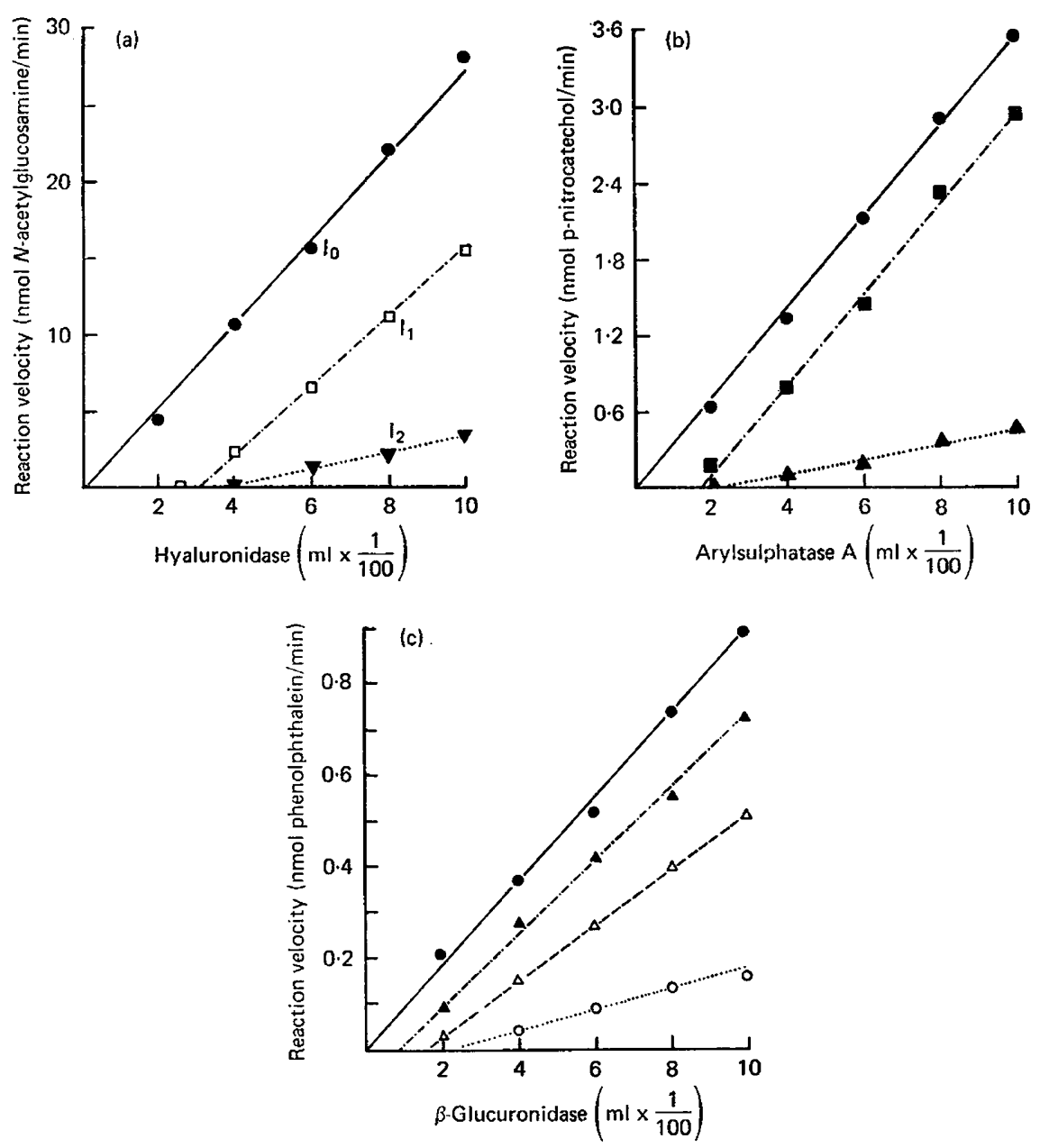

Text-fig. 2. Ackerman-Potter plots of the inhibition of (a) hyaluronidase, (b) aryl sulphatase A, and (c) $\beta$-glucuronidase by $\alpha$-chlorohydrin at various concentrations. Substrate concentrations were (a) $2.4 \mathrm{mg}$ hyaluronic acid/ml; (b) $3 \mathrm{~mm}-4$-nitrocatechol sulphate; and (c) $0.01 \mathrm{M}$-phenolphthalein glucuronic acid. Inhibitor concentrations were $0(0), 0.17(\square), 0.3(\Delta), 0.47(\square), 0.6(\Delta), 0.7(\nabla)$ and $1.2(0) \mathrm{M}$.

Further confirmation of the irreversibility of the hyaluronidase inhibition was given by measurement of the activities of hyaluronidase before and after dialysis of enzyme-inhibitor systems against distilled water. No change of activities was observed at two different concentrations of inhibitors after dialysis.

A Lineweaver-Burk plot of the kinetics of inhibition of hyaluronidase and $\beta$-glucuronidase by $\alpha$-chlorohydrin is shown in Text-fig. 3. The $K_{t}$ for hyaluronidase inhibition was $5 \cdot 4 \times 10^{-2} \mathrm{M}$ and for $\beta$-glucuronidase was $5 \times 10^{-1} \mathrm{M}$. Non-competitive inhibition (Webb, 1963) was demonstrated for both enzymes. 

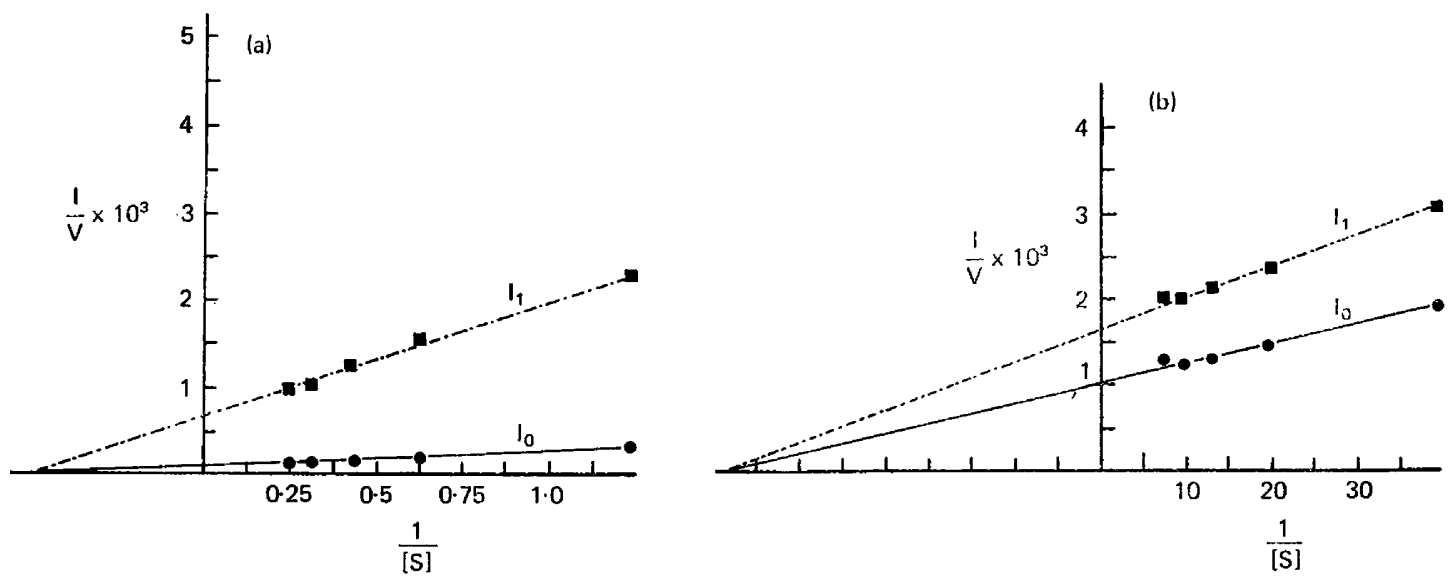

Text-fig. 3. Lineweaver-Burk plots of the activity of (a) hyaluronidase and (b) $\beta$-glucuronidase in the absence ( ) and presence ( $\square$ ) of $0.3 \mathrm{M}-\alpha$-chlorohydrin. The substrate concentrations were $0.8-4 \mathrm{mg}$ hyaluronic acid/ml for hyaluronidase and $0.25-1.25 \mathrm{~mm}$-phenolphthalein glucuronic acid for $\beta$-glucuronidase.

\section{Discussion}

Although the $K_{l}$ values obtained in this report are high, our data clearly indicate that $\alpha$-chlorohydrin inhibits hyaluronidase, aryl sulphatases and $\beta$-glucuronidase, but not acrosin and neuraminidase.

The mechanism of antifertility action of $\alpha$-chlorohydrin is not clarified. Jones \& Jackson (1974) reported that $\alpha$-chlorohydrin was ineffective as a sterilant in a test system involving fertilization in vitro of Xenopus laevis and suggested that $\alpha$-chlorohydrin might have some indirect effect on spermatozoa. It was also suggested that a sterilizing dose of $10 \mathrm{mg} \alpha$-chlorohydrin $/ \mathrm{kg}$ to male rats should not result in a concentration of the compound in vivo greater than $0.01 \mathrm{mg} / \mathrm{ml}$, i.e. $0.1 \mathrm{~mm}$. In contrast, the inhibition of enzymes in vitro required much larger amounts $(\times 1000)$ of the compound. The reasons for this are not clear except that the enzymes used were highly purified from a large volume of semen and the purified enzymes were very active. Since $\alpha$-chlorohydrin is an alkyl halide, it may function as an alkylating agent, as indicated by its reactivity with cysteine in vitro and the appearance in urine of alkylated cysteine metabolites after administration in vivo (Jones, Davis, Edwards \& Jackson, 1969).

Johnson \& Pursel (1973) found that the cauda epididymidis in the boar was the site of $\alpha$-chlorohydrin activity and suggested that $\alpha$-chlorohydrin might block an enzyme(s) on the sperm cell. These sites may be those of the glycosidases and sulphatases which are associated with spermatozoa. Consequently, inhibition of these enzymes may affect sperm transport by preventing these enzymes from acting on the mucoid material present in the male and female tracts, or may block the penetration of spermatozoa through the investments of the ovum.

This work was supported by NIH Contract No. 70-2147 and a Ford Foundation Grant No. 680-0805A.

\section{References}

ACkerman, W.W. \& Potter, V.R. (1949) Enzyme inhibition in relation to chemotherapy. Proc. Soc. exp. Biol. Med. 72, 1-9.
Conchie, J., Findlay, J. \& LeVvy, G.A. (1959) Mammalian glycosidases; distribution in the body. Biochem. J. 71, 318-325. 
Coppola, J.A. (1969) An extragonadal male antifertility agent. Life Sci. 8, 43-48.

ERICSSON, R.J. \& BAKER, V.F. (1970) Male antifertility compound: biological properties of U-5897 and U-15, 646. J. Reprod. Fert. 21, 267-273.

GunN, S.A., Gould, T.G. \& ANDERson, W.A.D. (1969) Possible mechanism of post-testicular antifertility action of 3-chloro-1,2-propanediol. Proc. Soc. exp. Biol. Med. 132, 656-659.

Johnson, L.A. \& Pursel, V.G. (1973) Alpha chlorohydrin: studies on the mechanism of action in male swine. J. Anim. Sci. 37, 1207-1211.

Jones, A.R., Davis, P., Edwards, K. \& Jackson, H. (1969) Antifertility effects and metabolism of $\alpha$ and epi-chlorohydrins in the rat. Nature, Lond. 224, 83.

JONES, P. \& JACKSON, H. (1974) Actions of antifertility chemicals on Xenopus laevis spermatozoa in vitro. J. Reprod. Fert. 38, 347-357.

Samojlik, E. \& Chang, M.C. (1970) Antifertility activity of 3-chloro-1,2-propanediol (U-5897) on male rats. Biol. Reprod. 2, 299-304.

SRivastava, P.N., Zaneveld, L.J.D. \& Williams, W.L. (1970) Mammalian sperm acrosomal neuraminidases. Biochem. Biophy's. Res. Commun. 39, 575-582.

Srivastava, P.N., Munnell, J.F., Yang, C.H. \& FolEY, C.W. (1974) Sequential release of acrosomal membranes and acrosomal enzymes of ram spermatozoa. J. Reprod. Fert. 36, 363-372.

Tarentino, A.L. \& Maley, F. (1972) $\beta$-N-Acetylglucosaminidase from hen oviduct. Methods Enzymol. 28, 772-776.

TURNER, M.A. (1971) Effects of $\alpha$-chlorohydrin upon the fertility of spermatozoa of the cauda epididymidis of the rat. J. Reprod. Fert. 24, 267-269.

VICKERY, B.H., ERICKSON, G.I. \& BENNETT, J.P. (1974) Mechanism of antifertility action of low doses of $\alpha$-chlorohydrin in the male rat. $J$. Reprod. Fert. 38, $1-10$.

WebB, J.L. (1963) Enzyme and Metabolic Inhibitors, Vol. I. Academic Press, New York.

YaNG, C.H. \& SRIvastava, P.N. (1972) Purification and properties of hyaluronidase isolated from bull seminal plasma. Biol. Reprod. 7, 101-102.

YaNG, C.H. \& SRIVASTAVA, P.N. (1974a) Separation and properties of hyaluronidase from ram sperm acrosomes. J. Reprod. Fert. 37, 17-25.

Yang, C.H. \& Srivastava, P.N. (1974b) Purification and properties of aryl sulfatases from rabbit sperm acrosomes. Proc. Soc. exp. Biol. Med. 145, 721-725.

YanG, C.H. \& SRivastava, P.N. (1975) Purification of bull sperm hyaluronidase by concanavalin $A$ affinity chromatography. Biochim. biophys. Acta 391, 382-387.

Received 2 April 1975 